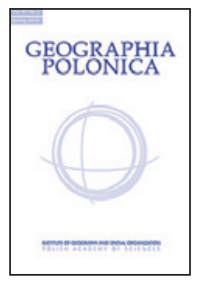

\title{
ECOLOGICAL AND CULTURAL IMPORTANCE OF JUNIPER ECOSYSTEM IN THE AREA OF ZERAVSHAN VALLEY (TAJIKISTAN) ON THE BACKGROUND OF ENVIRONMENTAL CONDITION AND ANTHROPOGENIC HAZARDS
}

\author{
Oimahmad Rahmonov ${ }^{1}$ - Małgorzata Rahmonov ${ }^{1}$ \\ Magdalena Opała-Owczarek ${ }^{1}$ - Piotr Owczarek ${ }^{2}$ \\ Tadeusz Niedźwiedź ${ }^{1}$ - Urszula Myga-Piątek ${ }^{1}$ \\ ${ }^{1}$ Faculty of Earth Sciences \\ University of Silesia in Katowice \\ Będzińska 60, 41-200 Sosnowiec: Poland \\ e-mail: oimahmad.rahmonov@us.edu.pl \\ ${ }^{2}$ Institute of Geography and Regional Development \\ University of Wroclaw \\ Uniwersytecki 1, 50-137 Wrocław: Poland
}

\begin{abstract}
The study analyses physiogeographical factors of the Zeravshan Range as a basis for environmental and habitat diversity. They provided the background for considering conditions for the functioning of juniper forest ecosystems. The uniqueness of these ecosystems also relies on the longevity of Juniperus seravschanica Kom., J. semiglobosa Regel and J. turkestanica Kom. Physiognomic features of the landscape are conditioned by the habitat, climate, landforms, and recently also by anthropopressure. The ecological, environmental and the cultural importance of juniper trees makes them a distinctive and determinant feature of the landscape. Currently juniper forests across Tajikistan, including those in the Zeravshan Mts., have been significantly disrupted as a result of chaotic, uncontrolled and excessive felling. The purpose of this article is to present natural conditions of juniper forest ecosystems, the impact of anthropogenic changes on their functioning as well as the occurrence of endemic species within them. The cultural importance of juniper in the protection of the surrounding landscape was also analysed.
\end{abstract}

\section{Key words}

juniper forest - deforestation - mountain vegetation - environmental conditions - Zeravshan Valley • Tajikistan 


\section{Introduction}

The Zeravshan Valley, as well as the entire area of the Republic of Tajikistan, is highly diverse in geological, geomorphological and climatic terms, both vertically and horizontally. This has led to the formation of habitat mosaics with floral landscapes characterised by a rich and unique vegetation cover. Forests of Central Asia are among the most valuable areas of the Earth in terms of biodiversity; they are considered a biodiversity hotspot (Mittermeier et al. 2005). In a relatively small area (93\% of Tajikistan is mountainous), there are over 5,000 species of vascular plants, of which 850 occur either solely in the territory of Tajikistan or slightly outside its borders (Abdusalâmov 1988).

Interest in researching plant landscapes of Tajikistan, including the Zeravshan region, appeared at the turn of the 19th and early 20th centuries (Borŝov 1865; Lipskij 1902). More detailed floristic studies in the area were conducted in the later decades of the 20th century (Gončarov 1937; Ovčinnikov 1940; Grigor ev 1944; Zakirov 1955, 1961; Stanûkovič 1963; Sidorenko et al. 1964; Konnov 1973; Safarov 1974; Kamelin 1979; Kudratov 1985). The above-mentioned studies concerned the use of natural resources and rational land use. Already back then scientist registered disruptions of natural processes in local ecosystems. The synthesis of fragmented research on nature conservation, geobotany and pedology in the Zeravshan Range can be found in the most important multi-author paper Flora Tadžickoj SSR (Ovčinnikov 1957, 1963, 1968, 1975, 1978, 1981; Stanûkovič 1973; Čukavina 1984; Kočkareva 1986; Kinzikaeva 1988; Rasulova 1991), which is generally the only available botanical literature on Tajikistan.

Within the Zeravshan Range the best-studied area in terms of geobotany and ecology is the catchment of the Iskanderdar. The research concerned the issues of the tree-shrub riparian communities around Lake Iskanderkul ('Iskandar' means Alexander the Great, 'kul' means lake) and the rivers feeding and draining it (Sadikov \& Darvoziev 2011). Syntaxonomic classification and an update regarding juniper forests of the area were conducted relatively recently (Ismailov et al. 2010ab, 2012; Sadikov 2012). It should be emphasised that the first detailed paper on the flora of the Iskander basin was developed in 1985 (Ismailov 1985). Recently research on vegetation succession on scree slopes and plant adaptation in such an extreme environment was initiated (Saidov \& Džuraev 2011). Moreover, relatively recently a paper was published on human impact on vegetation cover in the Kulikalon Basin and its natural consequences in the Fann Mts. (Rahmonov et al. 2011ab, 2013, 2016). Moreover, papers describing dendroclimatic potential of the species of the genus Ephedra and Juniperus were published (Opała et al. 2013, 2017).

Juniper forest ecosystems are rich in species, including rare and endemic ones. One of the causes of biodiversity and endemism is associated with the presence of orographic barriers. High mountain ranges inhibit migration of animals and spread of plants. As a result, isolated populations easily evolve into separate species. Large corries and deep valleys between mountain ranges show specific climatic and soil conditions, which in turn favoured the occurrence of species not found in other ecosystems. This is clearly evident in the form of well-developed soil cover and relatively thicker forests on the northern slopes than on insolated areas where evapotranspiration is very high.

The purpose of this article is to present natural conditions of juniper forest ecosystems, the impact of anthropogenic changes on their functioning as well as the occurrence of endemic species within them (the analysis of endemic species was based on specialist literature and field research). Moreover, the cultural importance of juniper in the protection of the surrounding landscape was also analysed.

\section{Materials and methods}

The materials were collected during field research and, in case of endemic species, were gathered from available specialist literature. The analysed material includes 
information collected in the years 20012015, partly through botanical expeditions conducted by workers of the Medical University in Dushanbe and a team from the University of Silesia. The study was conducted in the Zeravshan Valley, from the botanical perspective described as the Zeravshan Geobotanic District. The detailed observations of endemic plant species (especially within juniper ecosystem) in the east of the province, mainly in the Yaghnob Valley and in the upper part of the Zeravshan Valley, were carried out by a team of researchers under the direction of M. Kholbegov (Rahmonov et al. 2013, 2014). During the field work the occurrence of endemic species in juniper ecosystems of this region was tested, i.e. confirmed or not.
During investigations the sites of endemic plant species in that area were checked against the 10-volume Flora Tadžickoj SSR where the location of these species is given. Botanic and habitat documentation for 140 species from 190 included in this book and which occur within the limits of this geobotanic district was collected. Also Latin names of species were given after the Flora Tadžickoj SSR. In terms of geobotanic regionalisation of the Republic of Tajikistan, the studied area belongs to the Zeravshan region located within the massif of the Zeravshan Range (Fig. 1). The valley of the Zeravshan and its catchment show highly diverse environmental conditions, hence the division into three Zeravshan geobotanic subdistricts: West (A), Central (B) and Eastern (C).

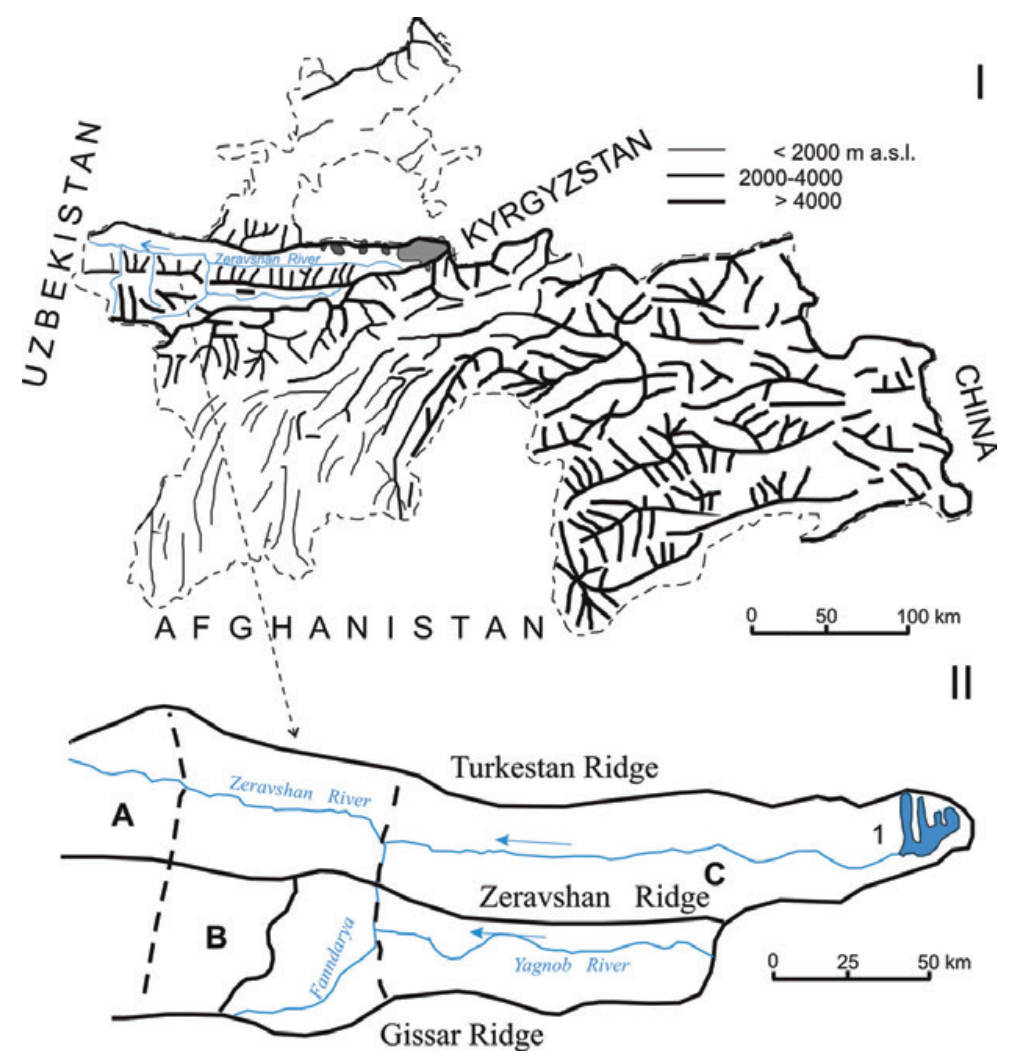

Figure 1. I - Distribution of the main mountain ridges in Tajikistan, the arrow indicate the Zeravshan River catchment with the Zeravshan Glacier (gray area) (after Trohimov 1968); II - Zeravshan Geobotanical Region: A - western subregion, B - central subregion and C - eastern subregion; 1 - Zeravshan Glacier (after Rahmonov et al. 2013, changed) 


\section{Environmental conditions of Zeravshan valley}

\section{Relief and geology}

The Zeravshan Range is located in north-west Tajikistan; it runs from the west to the east along the stretch of about $300 \mathrm{~km}$. The range belongs to the extensive Pamir-Alay Mts. which form the transition zone between the Pamir and Tian-Shan Mts. The average width of the Zeravshan Range reaches $50 \mathrm{~km}$. In the north it is separated from the Turkestan Mts. by the Zeravshan Valley, whereas in the south the Yagnob Valley separates it from the Gissar Range (Fig. 1).

Thanks to their unique landscape (emerald lakes, glaciers, precipitous slopes, juniper forests, rocky walls of mountain peaks) they are called 'the pearl' of the Pamir-Alay. The Zeravshan Range also owes its beauty to the highly picturesque high mountain Lake Iskanderkul, situated in the heart of the massif of the Fann Mts.

The Zeravshan Range was finally uplifted during the Alpine orogeny but neo-tectonic processes are observed. This region shows high seismicity connected with the location in the vicinity of the frontal Pamir thrust system (Owczarek et al. 2017). Deposits from the Middle Devonian and Carboniferous predominate. Northern foothills are partially built of Lower Silurian rocks, whereas in the western part of the mountains Neogene deposits predominate, among which the Lower Silurian is also represented (Vinničenko \& Tadžibekov 2010). On the southern slopes Cretaceous material is occasionally observed. These rocks are represented by crystalline schists, granites, limestones, quartzites, sandstones and conglomerates. There are widespread covers of Quaternary deposits: Pleistocene and Holocene.

The average height of the Zeravshan Range is $4,110 \mathrm{~m}$ a.s.l., while the maximum elevation reaches $5,489 \mathrm{~m}$ a.s.l. (Chimtargha Peak, Fig. 2). The highest parts have glacial relief with glacial cirques, partly covered by modern glaciers, U-shaped valleys, as well as terminal and lateral moraine ridges. Steep slopes are covered with a thick layer of loose sediment, where the dominant geomorphic processes are sliding and falling. These

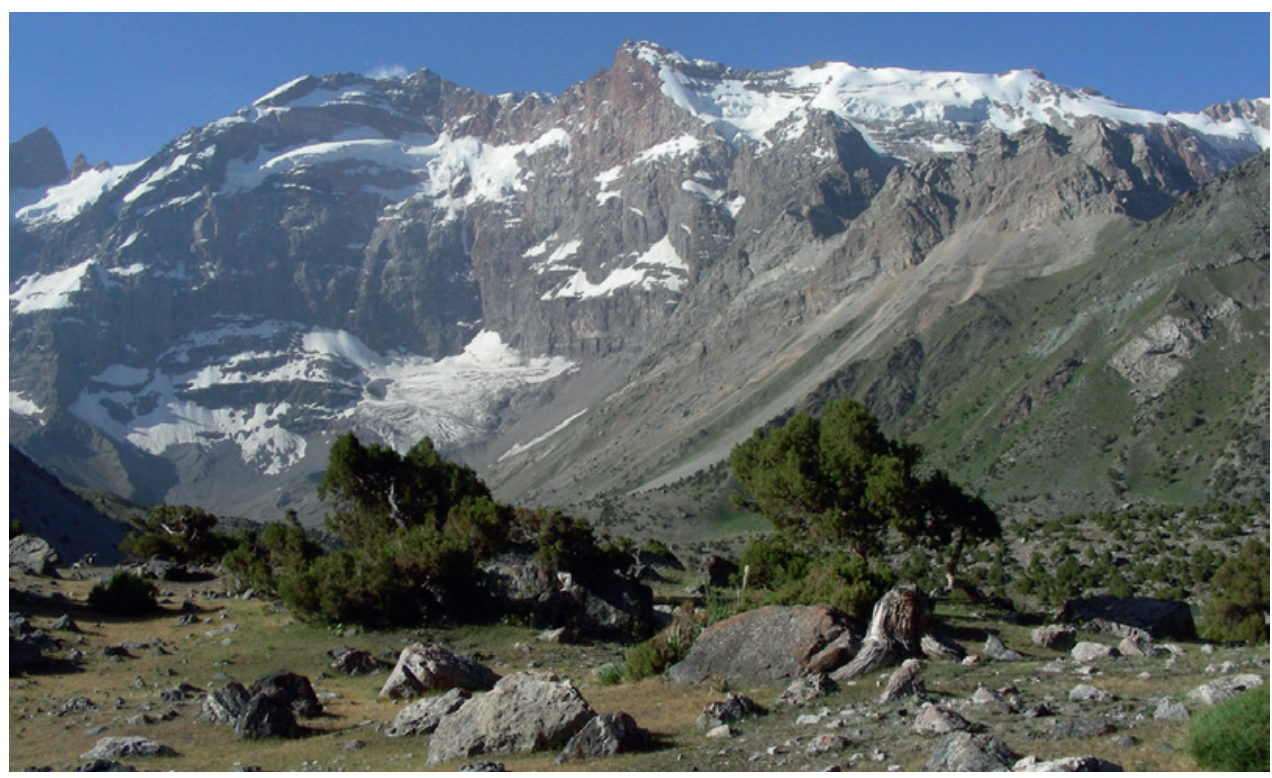

Figure 2. The typical high-mountain landscape of the Fann Mountains in the surroundings of Kulikalon depression with the Chimtargha Peak in the background; the flat area and lower parts of slopes are covered by juniper woodland (photo: O. Rahmonov) 


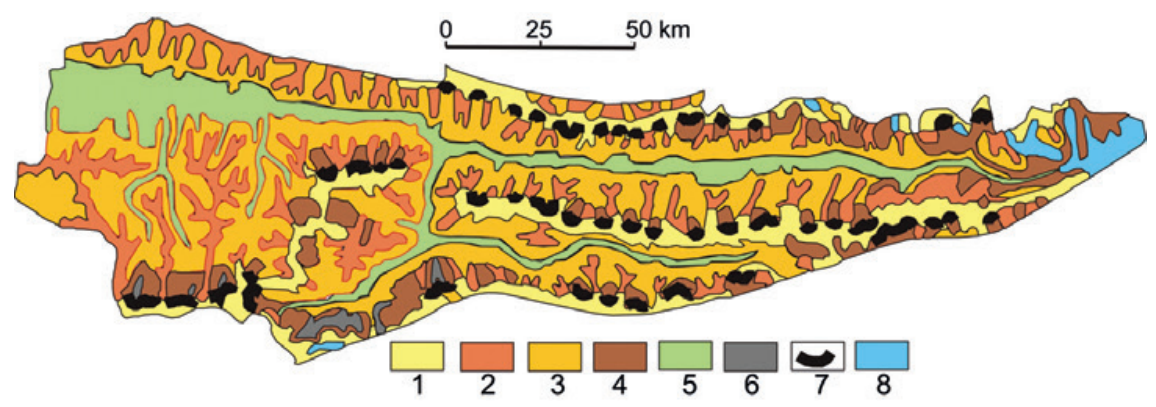

Figure 3. The geomorphological scheme of the Zeravshan Ridge in background of Zeravshan Geobotanical Region (Trohimov 1968, changed): 1- flat-topped mountains, 2 - narrow ridges, 3 - V-shaped valleys, 4 - mountain ridges transformed by nival and exaration processes, 5 - alluvial and proluvial-alluvial surfaces, 6 - end and lateral moraines, 7 - glacial cirques and 8 - main glaciers

processes are often connected with the seismic activity of the Pamir region (Owczarek et al. 2017). The lowest point occurs in the western part of the Zeravshan Range, rising to a height of 2,000 $\mathrm{m}$ a.s.I., where clear developed karst landforms are visible. Compared to the Fann Mts. to the east, the Zeravshan Range is much higher and represents highmountain relief. Its northern slopes are intensively undercut by transverse valleys of the left tributaries of the Zeravshan. The uppermost sections of these valleys are mostly occupied by glaciers. The southern slopes of the mountains are often more uniform and much less dissected by valley forms (Fig. 3). The analysed area is often called Kukhistan ('country of mountains').

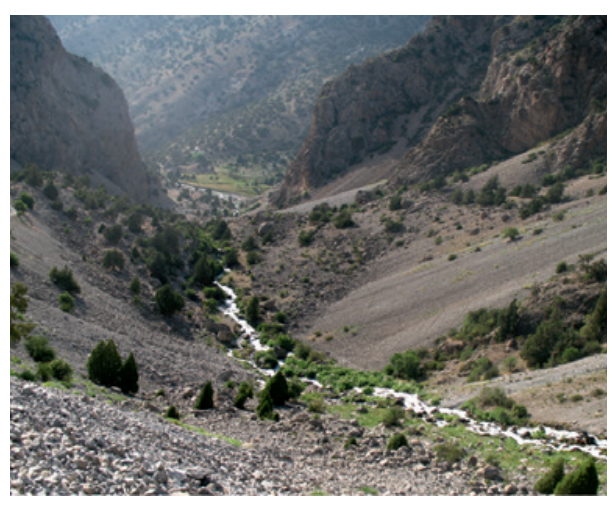

Figure 4. U-shaped valley filled by Quaternary deposits; Pleistocene lateral moraine in the foreground (photo: O. Rahmonov)
The eastern part of the Zeravshan Range is characterised by large elevation ranges along relatively short distances. This has undoubtedly a significant impact on the diversity of landscape and its mosaic character. High and steep ridges as well as narrow and deep valleys are characteristic elements of the landscape (Fig. 4). Such relief promotes intensive sheet-wash processes that damage soil cover down to the bedrock. The eastern border of the region, called the Matcha node, is occupied by the Zeravshan Glacier - the source of the Zeravshan River (see Fig. 1). From this mountain node the ranges of the Zeravshan, Turkestan and Gissar branch out towards the west. The ridges of the Zeravshan Range are mostly located above the snow line, and thus there are numerous glaciers on its northern slopes. The largest of them are concentrated in the eastern part of these mountains (Fig. 3).

\section{Water conditions}

Between the mountain ranges of the Zeravshan and Turkestan flows one of the largest rivers in Central Asia - the Zeravshan (means 'spreader of gold'). This river used to be one of the longest and full-flowing right tributaries of the Amu Darya (Fig. 5). In 1874 and 1921 during high water it reached the Amu Darya. Today, the Amu Darya water is used for agriculture through a system of canals and other hydrological structures (Abrorov 2005). 


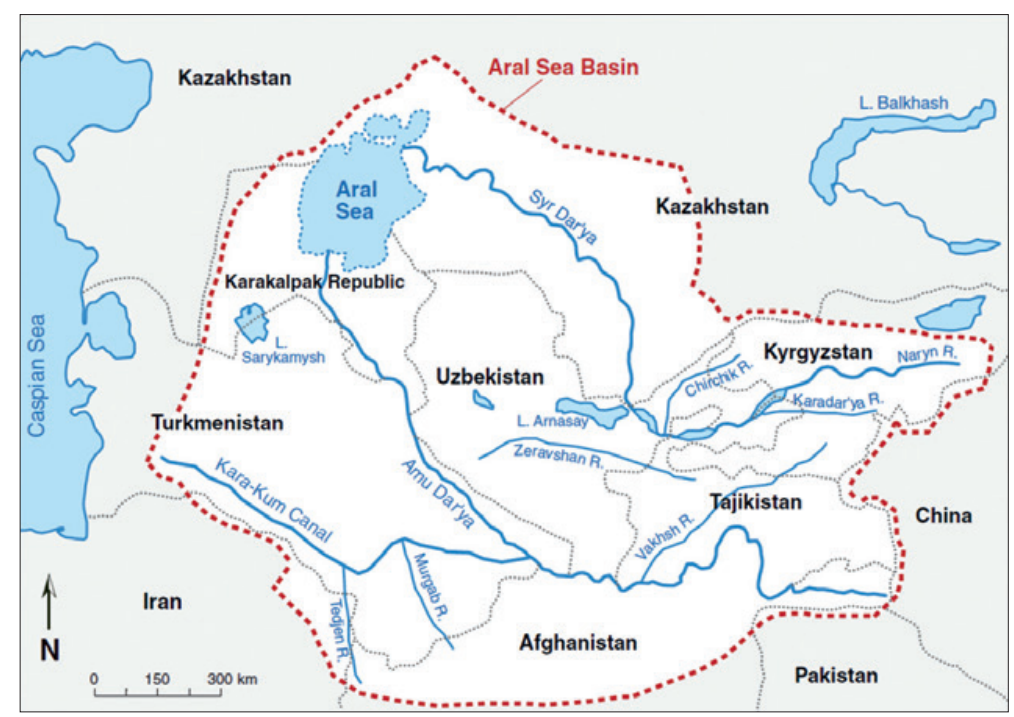

Figure 5. The Zeravshan River on the background of Aral Sea basin (after Micklin 2007). The river ends of its course in the sands of Kyzyl-Kum Desert not reaching the Amu Darya

This is one of the causes of the ecological disaster affecting the ecosystem of the Aral Sea. However, local climate conditions do not allow high-yield to be achieved in virtually any sectors of agriculture without irrigation. The total length of the river from the Zeravshan Glacier to Lake Dengizkul (Uzbekistan) is 877 km, including $316 \mathrm{~km}$ in Tajikistan; the surface area of its basin is $43,000 \mathrm{~km}^{2}$. The river system of the Zeravshan catchment is not complex, but unevenly distributed. The river is fed by over 200 small and large rivers; about 80 of them are over $10 \mathrm{~km}$ long, and 3 are over $50 \mathrm{~km}$ long (Abrorov \& Šermatov 2010). The most important tributaries of the Zeravshan include: the Yagnob, Iskander Darya ${ }^{1}$, Matche, Fan Darya, Kishtud, Moghiyon.

The Zeravshan and its main tributaries are fed by snow and glacier meltwater (generally in the Zeravshan catchment there are 1,272 tributaries), while seasonal rainfall does not have a major impact on the development of the river regime (Abrorov \& Šermatov 2010). High water is recorded between May and

$11.3 \mathrm{~km}$ down the river from Lake Iskanderkul the Zeravshan forms a 24-m waterfall. Tourists symbolically call it the Fann Niagara. The waterfall was discovered in 1889 by Russian explorer and naturalist V.I. Lipskij.
September. The largest discharge is recorded in July, while the lowest in February. Most of the Zeravshan basin has steep slopes; during floods water reaches high velocities and carries large amount of sediment in suspension.

Over its entire course, the Zeravshan follows a diverse channel (broad, narrow, deep), depending on the geological and geomorphological conditions. Along longer stretches it reveals a braided character, while near the town of Panjakent it develops an anastomosing character - it is divided into many braids separated by islands covered with tugay-type communities. This zone is also used as rice fields. At these stretches the river width reaches two kilometres.

\section{Climate conditions}

Climate conditions of the Zeravshan Range are diverse, depending on the altitude, which reaches up to $5,489 \mathrm{~m}$ a.s.l. (Chimtargha Peak, Fann Mts.). The study considers the mean temperature and precipitation data (Trohimov 1968; Williams \& Konovalov 2008; Opała et al. 2017), available for a long period of time (40-60 years) from a few meteorological stations in this region of Tajikistan. 
Mean yearly precipitation for the discussed area is $400-500 \mathrm{~mm}$ on peaks and slopes at the altitudes of about $3,000-3,400 \mathrm{~m}$ a.s.l. (418 $\mathrm{mm}$ on the Anzob Pass at 3,373 m a.s.l.). In basins and deep valleys (altitudes of 2,200-2,500 m a.s.l.), precipitation drops to $250-300 \mathrm{~mm}(271 \mathrm{~mm}$ in Iskanderkul at 2,204 $\mathrm{m}$ a.s.l.). Most precipitation occurs in the spring season $(60-70 \mathrm{~mm}$ in April or May), while winter features low snowfall.

Mean temperatures reach about $15-16^{\circ} \mathrm{C}$ (maximum: $25-26^{\circ} \mathrm{C}$ ) in summer and -5 to $-8^{\circ} \mathrm{C}$ (minimum: -25 to $-26^{\circ} \mathrm{C}$ ) in winter. The period without ground frost or air frost reaches 90-100 days a year (Sadikov 2012). Throughout the year, the warmest month is July (less frequently August). The vertical gradient of mean temperature of the warmest month is $-0.7^{\circ} \mathrm{C} / 100 \mathrm{~m}$, which is higher than the yearly gradient. The temperature in July ranges from about $21^{\circ} \mathrm{C}$ at $1,700 \mathrm{~m}$ a.s.l. to $10^{\circ} \mathrm{C}$ at 3,300 $\mathrm{m}$ a.s.l. near the upper line of juniper forests (Rahmonov et al. 2017).

\section{Soil diversity}

In the Zeravshan Range four morphological types of relief are distinguished: foothill-planar, alpine low, alpine medium and alpine high. Each of these types is specific and presents different soil-forming processes. Significant land areas, especially in the upper reaches of the Zeravshan, lack soil cover: the bedrock is visible directly on the surface, and some parts are covered with active scree slopes and glaciers. Steep mountain slopes do not provide favourable conditions for soil formation; snow and rubble avalanches a frequent phenomenon - tear off the surface and destroy initial vegetation.

Such specific physiogeographical features in this area are conducive to the formation of a specific type of local soil and climatic conditions. The soil cover is heterogeneous, both in terms of mechanical composition and development stage. Depending on the topography, aspect, altitude and vegetation, soils range from fine-grained to poorly developed coarse-grained skeleton soils. Soil profiles are very shallow; the thickest ones occur on loess plains in the western part of the Zeravshan Valley, which is dominated by the cultivation of rice and cereals as well as vineyards and fruit orchards.

Given great altitude ranges in the area of the Zeravshan Geobotanic District, the following several different soil types have been delimited (Kuteminskij 1960; Kuteminskij \& Leonty 'eva 1966): light brown mountain soils (under juniper and steppe juniper forests), brown mountain soils (under junipers, mixed mesophilic forests), mountain and high-mountain steppe soil (cushion plants, creeping juniper), light grey earths, dark grey earths, common grey earths, and poorly developed skeleton soils. Significant areas are either devoid of the soil cover completely (perennial snow patches), or the soil cover is poorly developed (rocks, active stone run). Solonchaks and hydrogenic soils take an important place in the area. In natural conditions they are found in the lower parts of the mountains and in the Zeravshan Valley, especially in its head reaches on the territory of Tajikistan. They have developed under riparian communities, so-called tugay or tugai, composed of a variety of species, mainly from the genera Populus and Salix.

Due to their fertility, valley areas are massively used for agriculture. Although most of the crops are located directly in the valley or not far from it, they require irrigation because of high temperatures and rapid drying of the soil. As in the majority of the area soils have been anthropogenised; thus their chemical composition and structure do not reflect similar units in undisturbed areas (Hagedorn et al. 2010). Anthropopressure has also led to the disappearance of many plant species and decrease in total biodiversity.

\section{Main vegetation types in the Zeravshan Range}

In the Zeravshan Geobotanic Region four altitudinal zones have been delimited (Fig. 6). The first zone (1,200-2,000 $\mathrm{m}$ a.s.l.) occupies salt sagebrush deserts with the dominant participation of Artemisia tenuisecta, A. porrecta and a number of other halophytic species. 


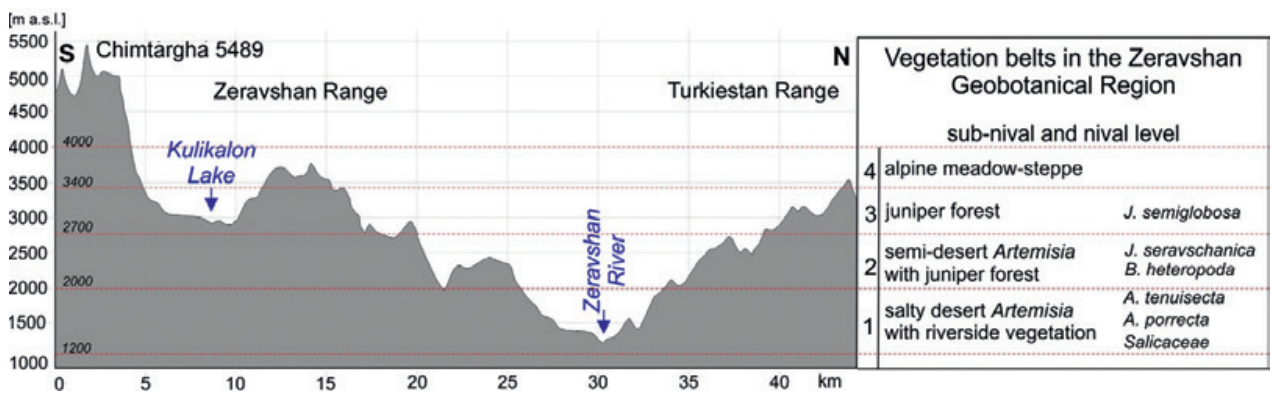

Figure 6. Cross-section through the Zeravshan River valley with geobotanical zones depending on elevation (on the base of topographic map)

At the altitude of 2,000-2,700 m a.s.l. (second zone) there are patches of sagebrush desert with juniper forests, mainly with the participation of J. seravschanica and shrubs: Berberis heteropoda, B. integerrima, Cotoneaster nummularioides, Lonicera nummulariifolia, L. simulatrix, Sorbus tianschanica. In the third zone (2,700-3,400 m a.s.I.) steppe patches of various sizes with Festuca sulculcata, Artemisia dracunculus are observed. At the altitude of 2,500-2,800 m a.s.l. there is a transition belt with J. seravschanica and J. semiglobosa. Above this latitude Juniperus semiglobosa forms homogenous forests, deciding the physiognomy of this high-mountain forest (Zaprâgaev 1976). Cushion vegetation and spiky grasslands, which dominate at the elevation of 3,400-4,000 m a.s.l., form the last altitudinal vegetation zone.

Within the delimited vegetation zones in the Zeravshan Range eight basic types of ecosystems are distinguished: alpine desert, alpine meadow-steppe, medium-mountain coniferous forests, medium-mountain of mesophilic forests, medium-mountain of xerophilic sparse forests, medium and low-mountain semi-savanna (savanna-like), aquatic and coastal, as well as agroecosystems (Fig. 7). Forest ecosystems, especially juniperous forest, are more diverse and thus more interesting to researchers. They show richness of plant species with a variety of ecological requirements. All the mentioned ecosystems are predominantly distributed within the juniper ecosystem and are relatively well preserved. In such phytocoenosis of the Zeravshan Range, a huge number of rare and endemic species have been preserved. Juniper ecosystems, thus, play an important role in the conservation of vegetation diversity at the genetic and ecosystems level.

As has already been mentioned, the entire area of Tajikistan, including the Zeravshan Range, shows high floristic diversity. This diversity, resulting from varied relief, microrelief, climate, microclimate and topoclimate reflecting altitudinal zonation, has contributed to the development of plant species specific only to this geographical region, i.e. endemic species. The different species are associated with a specific type of ecosystem and specified altitude. The diversity of endemic species within the ecosystems of the Fann Mts. is shown in Figure 7.

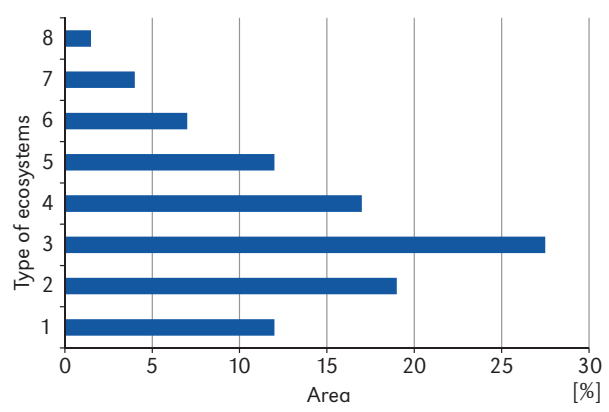

Figure 7. The area (in \%) occupied by certain types of ecosystems in the Zeravshan valley: 1 - high mountain desert ecosystems, 2 - high mountain meadow and steppe ecosystems, 3 - mid-mountain conifer forest ecosystems, 4 - mid-mountain mesophyllic forest ecosystems, 5 - mid-mountain xerophytic light forest ecosystems, 6 - mid-lowmountain semisavanna (savannoide) ecosystems, 7 - wetland ecosystems, 8 - agroecosystems (the names correspond to Table 1) 
Table 1. The list of endemic plant species of Zeravshan Ridge (after Flora Tadžickoj SSR, Rahmonov et al. 2013, changed)

\begin{tabular}{|c|c|c|c|}
\hline Families / species & $\begin{array}{c}\text { Type of } \\
\text { ecosystems }\end{array}$ & $\begin{array}{l}\text { Altitude } \\
\text { m a.s.l. }\end{array}$ & Subregion \\
\hline \multicolumn{4}{|l|}{ Gramineae } \\
\hline Poa articulata Ovcz. & 7 & $2500-3000$ & B \\
\hline Festuca squamulosa Ovcz. & 6 & $600-1600$ & B \\
\hline Zerna Paulsenii (Hack.) Nevski & 2 & $2700-3600$ & B \\
\hline Roegneria interrupta Nevski & 3 & $2300-3600$ & $A, B, C$ \\
\hline Elytrigia setulifera Nevski & 2,3 & $2300-3200$ & $B, C$ \\
\hline Helictotrichon hissaricum (Roshev.) Henr. & 2,3 & $2300-3200$ & $B, C$ \\
\hline Stipa jagnobica Ovcz. & 3 & to 2600 & A \\
\hline S. Ovczinnikovii Roshev. & 5,6 & $1300-1800$ & C \\
\hline Piptatherum Fedtschenkoi Roshev. & $4-6$ & $1800-3200$ & $B, C$ \\
\hline${ }^{\star P}$. pamiroalaicum (Grig.) Roshev. & 1,2 & $2600-4150$ & $B, C$ \\
\hline \multicolumn{4}{|l|}{ Liliaceae } \\
\hline${ }^{\star}$ Merendera hissarica Regel & 1,2 & $3500-4000$ & $B, C$ \\
\hline Eremurus hissaricus Vved. & 3,4 & $2600-3000$ & C \\
\hline Gagea leucantha M. Pop. et Czug. & 2 & to 3500 & B \\
\hline G. minutissima Vved. & 1,2 & $3500-4000$ & B \\
\hline${ }^{\star}$ G. paedophila Vved. & 4,5 & $1200-2400$ & C \\
\hline Asparagus Komarovianus Vved. & 5 & $1800-2000$ & A \\
\hline \multicolumn{4}{|l|}{ Amaryllidaceae } \\
\hline Allium glaciale Vved. & 2,3 & $3000-3100$ & C \\
\hline${ }^{\star}$ A. darvasicum Regel & 3,4 & $2000-3300$ & B \\
\hline \multicolumn{4}{|l|}{ Salicaceae } \\
\hline Populus tadshikistanica Kom. & $4,7,8$ & $500-3000$ & C \\
\hline \multicolumn{4}{|l|}{ Betulaceae } \\
\hline Betula seravschanica V. Vassil. & $3,4,7$ & $1800-2800$ & $B, C$ \\
\hline B. alajica Litv. & $3,4,7$ & $1700-3000$ & $B, C$ \\
\hline B. pamirica Litv. & $3,4,7$ & $2300-3650$ & $B, C$ \\
\hline B. Regeliana $\vee$. Vassil. & $3,4,7$ & $2500-2800$ & B \\
\hline \multicolumn{4}{|l|}{ Santalaceae } \\
\hline Thesium Gontscharovii Bobr. & 3 & $1700-2300$ & B \\
\hline \multicolumn{4}{|l|}{ Polygonaceae } \\
\hline Rheum hissaricum Losinsk. & 2,3 & $2000-3000$ & $B, C$ \\
\hline R. Fedtschenkoi Maxim. ex Regel & 2 & $3100-3700$ & A \\
\hline Polygonum myrtillifolium Kom. & 2,3 & $2900-3600$ & $B, C$ \\
\hline \multicolumn{4}{|l|}{ Ranunculaceae } \\
\hline *Nigella bucharica Schipcz. & 5,6 & $520-1700$ & C \\
\hline Delphinium propinquum Nevski & 1,2 & $3500-4000$ & $B, C$ \\
\hline D. Nevskii Zak. & 2 & $2400-2600$ & A \\
\hline${ }^{\star} D$. ternatum Huth. & 4,5 & $1200-2400$ & B \\
\hline${ }^{\star} D$. Ovczinnikovi Kam. et Pissjauk. ex Kam. & 3,4 & $1200-1900$ & B \\
\hline Aconitum zeravschanicum Steinb. & 1,2 & $2400-3600$ & $A, B, C$ \\
\hline Anemone seravschanica Kom. & 3,4 & $1200-2000$ & $A, B, C$ \\
\hline
\end{tabular}




\begin{tabular}{|c|c|c|c|}
\hline Families / species & $\begin{array}{c}\text { Type of } \\
\text { ecosystems }\end{array}$ & $\begin{array}{l}\text { Altitude } \\
\text { m a.s.l. }\end{array}$ & Subregion \\
\hline *Ranunculus baldshuanicus Ovcz. et Koczk. & $3-5$ & $750-2200$ & B \\
\hline R. alpigenus Kom. & 3,4 & $2000-3300$ & $A, B, C$ \\
\hline R. turkestanicus Franch. & $1,2,7$ & $2000-3500$ & $A, B$ \\
\hline R. Botschantzevii Ovcz. & 2 & $3300-3500$ & A \\
\hline \multicolumn{4}{|l|}{ Berberidaceae } \\
\hline \multicolumn{4}{|l|}{ Crassulaceae } \\
\hline Pseudosedum condensatum Boriss. & $1-3$ & $2100-3600$ & $B, C$ \\
\hline P. Fedtschenkoanum Boriss. & $4-6$ & $450-2200$ & B \\
\hline \multicolumn{4}{|l|}{ Saxifragaceae } \\
\hline \multicolumn{4}{|l|}{ Rosaceae } \\
\hline Cotoneaster zeravschanicus Pojark. & $4-6$ & $1900-2500$ & $A, B, C$ \\
\hline *Potentilla pamirica Th. Wolf & 1,2 & $2900-4800$ & C \\
\hline ^P. Vvedenskyi Botsch. & 1,2 & $2900-3800$ & $B, C$ \\
\hline P. flabellata Regel et Schmalh. & 1,2 & $3000-4200$ & $A, B, C$ \\
\hline P. mollissima Lehm. & 3,4 & $1800-3200$ & $B, C$ \\
\hline${ }^{\star P}$. darvasica Juz. ex Botsch. & 2,3 & $2300-3200$ & $A, B$ \\
\hline Alchemilla Verae Ovcz. & $2,3,7$ & to 2700 & $B$ \\
\hline A. biradiata Ovcz. & $2,3,7$ & $2400-3000$ & $B, C$ \\
\hline${ }^{\star}$ A. hissarica Ovcz. et Koczk. & $3,5,7$ & $2000-3500$ & $B, C$ \\
\hline A. fontinalis Juz. & $2,3,7$ & $2400-3200$ & C \\
\hline${ }^{\star}$ Rosa huntica Chrshan. & 7 & $1400-3000$ & $B, C$ \\
\hline R. achburensis Chrshan. & 4,5 & $400-2200$ & B \\
\hline R. Popovii Chrshan. & 8 & $1600-2900$ & C \\
\hline \multicolumn{4}{|l|}{ Cruciferae } \\
\hline Erysimum samarkandicum M. Pop. & 3,5 & $1500-2900$ & $A, B, C$ \\
\hline${ }^{\star}$ Cardamine densiflora Gontsch. & 3,7 & $2700-3400$ & $A, B$ \\
\hline C. seravschanica Botsch. & 3 & to 2700 & B \\
\hline Pseudoclausia Olgae (Regel et Schmalh.) Botsch. & 5 & to 1700 & A \\
\hline Parrya fruticulosa Regel et Schmalh. & 3,4 & $2200-2900$ & B \\
\hline${ }^{\star} P$. runcinata (Regel et Schmalh.) N. Busch & 2,3 & $2400-3600$ & $B, C$ \\
\hline${ }^{\star P}$. turkestanica (Korsh.) N. Busch & 1,2 & $3300-4500$ & $B, C$ \\
\hline${ }^{\star}$ Matthiola integrifolia Kom. & $3,5,6$ & $900-3000$ & $A, B, C$ \\
\hline Iskandera hissarica N. Busch & 2,3 & $2600-3200$ & $A, B$ \\
\hline${ }^{\star}$ Draba physocarpa Kom. & 1,2 & $2700-4300$ & $\mathrm{C}$ \\
\hline D. hissarica Lipsky & 1,2 & $3400-3800$ & $B, C$ \\
\hline D. alticola Kom. & 1,2 & $3000-3700$ & $B, C$ \\
\hline Lepidium seravschanicum Ovcz. et Junuss. & 3,5 & $1600-2200$ & $A, B, C$ \\
\hline \multicolumn{4}{|l|}{ Leguminosae } \\
\hline ^Thermopsis dolichocarpa V. Nikit. & $4-6$ & $960-2800$ & C \\
\hline Melissitus iskanderi (Vass.) Latsch. & 4,5 & $2000-2100$ & B \\
\hline${ }^{\star}$ Colutea hybrida Shap. & $3,5,6$ & $700-2400$ & B \\
\hline Chesneya kschtutica Rassul. et B. Sharipova & 2,3 & $2000-3100$ & $B, C$ \\
\hline
\end{tabular}




\begin{tabular}{|c|c|c|c|}
\hline Families / species & $\begin{array}{c}\text { Type of } \\
\text { ecosystems }\end{array}$ & $\begin{array}{l}\text { Altitude } \\
\text { m a.s.l. }\end{array}$ & Subregion \\
\hline Tragacantha transoxana (Fisch.) Kuntze & 5,6 & $650-1000$ & C \\
\hline T. macrantha Boriss. & 2,3 & $2000-3000$ & $B, C$ \\
\hline${ }^{\star}$ Oxytropis Lehmanni Bunge & 1,2 & $2300-3800$ & $B, C$ \\
\hline O. Michelsonii B. Fedtsch. & $1-3$ & $2300-3300$ & $A, B$ \\
\hline${ }^{\star} O$. immersa v. kussavliensis Abduss. subsp. nova in Addenda & 1 & $3100-3800$ & $\mathrm{C}$ \\
\hline O. lithophila Vass. & 3 & $2400-2700$ & B \\
\hline O. Ovczinnikovii Abduss. & 2,4 & $1550-3100$ & C \\
\hline O. kuhistanica Abduss. & 1,2 & $2900-3800$ & C \\
\hline O. pamiroalaica Abduss. & 1,2 & $2600-3700$ & C \\
\hline O. iskanderica B. Fedtsch. & 1,2 & $2500-3600$ & $A, B$ \\
\hline O. leptophysa Bunge & $3-5$ & $1400-2700$ & $A, B, C$ \\
\hline O. trichosphaera Freyn & 1,2 & $2500-3900$ & C \\
\hline Ewersmannia sogdiana Ovcz. & 5 & $1700-1800$ & B \\
\hline Hedysarum Korshinskyanum B. Fedtsch. & 5,6 & $1000-1400$ & B \\
\hline H. mogianicum B. Fedtsch. & $3,5,6$ & $1300-2000$ & $A, B$ \\
\hline Onobrychis seravschanica B. Fedtsch. & 3,4 & $1800-2700$ & C \\
\hline Lathyrus mulkak Lipsky & $3,4,6$ & $1200-3000$ & B \\
\hline Astragalus macropodium Lipsky & $4-6$ & $1200-3100$ & $B, C$ \\
\hline A. bibracteatus Ovcz. et Rassul. & 2,3 & to 3050 & C \\
\hline A. madruschkendicus Ovcz. et Rassul. & 3 & to 2700 & C \\
\hline A. czapdarinus Ovcz. et Rassul. & 3,7 & to 2500 & B \\
\hline A. leptophysus Vved. & $3-5$ & $1700-3000$ & C \\
\hline A. quisqualis Bunge & $1-5$ & $850-3600$ & $B, C$ \\
\hline${ }^{\star}$ A. acormosus N. Basil. & 4,6 & $1300-2880$ & B \\
\hline${ }^{\star} A$. pauper Bunge & $1-3$ & $2400-3500$ & $B, C$ \\
\hline${ }^{\star}$ A. pauperiformis B. Fedtsch. & 3 & $2800-2900$ & A \\
\hline${ }^{\star}$ A. schutensis Gontsch. & 2,3 & $3000-3500$ & A \\
\hline${ }^{\star}$ A. Aphanassjievii Gontsch. & 3,4 & $2500-3300$ & $B, C$ \\
\hline A. indurescens Gontsch. & 1,3 & $2900-3000$ & $A, B$ \\
\hline${ }^{\star}$ A. Zaprjagaevii Gontsch. & $2-4$ & $2000-3200$ & C \\
\hline A. apiculatus Gontsch. & 3,4 & $2700-3100$ & A \\
\hline A. sericeopuberulus Boriss. & 2,3 & $2500-3550$ & $A, B$ \\
\hline A. farctissimus Lipsky & 3 & $1800-1900$ & A \\
\hline${ }^{\star}$ A. kaschkadarjensis Gontsch. & 2,3 & $2900-3200$ & A \\
\hline A. exasperatus N. Basil. & 5,6 & $1600-2000$ & $A, B$ \\
\hline${ }^{\star}$ A. nigrocalyx Slobod. & $2-4$ & $2000-3500$ & C \\
\hline${ }^{\star} A$. roschanicus B. Fedtsch. & $1-3$ & $1800-3650$ & $B, C$ \\
\hline A. intarrensis Franch. & 3,5 & $1100-2800$ & $A, B, C$ \\
\hline A. longisepalus Rassul. & 2,3 & $2800-3100$ & C \\
\hline A. saratagius Bunge & $1-3$ & $2000-3500$ & $A, B, C$ \\
\hline${ }^{\star} A$. saratagius $v$. artschamajani Rassul. subsp. nova in Addenda & 3,4 & $2200-2300$ & B \\
\hline${ }^{\star}$ A. saratagius v. sarimensis Rassul. subsp. nova in Addenda & 2,3 & $3000-3100$ & B \\
\hline A. kschtutensis Rassul. & 2,3 & $2500-3200$ & $A, B$ \\
\hline A. urgutinus Lipsky & 5,6 & $1150-1700$ & B \\
\hline A. polytimeticus M. Pop. & 3,4 & $1500-2800$ & B \\
\hline
\end{tabular}




\begin{tabular}{|c|c|c|c|}
\hline Families / species & $\begin{array}{c}\text { Type of } \\
\text { ecosystems }\end{array}$ & $\begin{array}{l}\text { Altitude } \\
\text { m a.s.l. }\end{array}$ & Subregion \\
\hline A. Iksanderi Lipsky & $3-5$ & $1800-2900$ & $B, C$ \\
\hline A. neurophyllus Franch. & $4-6$ & $1100-2000$ & $A, B, C$ \\
\hline A. heterotrichus Gontsch. & $3-5$ & $1100-2700$ & $B, C$ \\
\hline A. rumpens Meffert & $3,5,6$ & $900-2700$ & $A, B$ \\
\hline${ }^{\star}$ A. melanocomus M. Pop. & 3,4 & $2100-2700$ & C \\
\hline${ }^{\star} A$. semideserti Gontsch. & 3,5 & $1700-2100$ & A \\
\hline $\begin{array}{l}\text { A. nobilis Bunge ex B. Fedtsch. } \\
\text { Linaceae }\end{array}$ & $3-5$ & $1500-2900$ & $A, B, C$ \\
\hline $\begin{array}{l}\text { Linum macrohizum Juz. } \\
\text { Euphorbiaceae }\end{array}$ & $1-4$ & $1900-3600$ & $B, C$ \\
\hline${ }^{\star}$ Andrachne Fedtschenkoi Koss. & 5,6 & $1200-1800$ & $A, B, C$ \\
\hline Euphorbia transoxana Prokh. & $2-4$ & $2300-2900$ & C \\
\hline $\begin{array}{l}\text { E. polytimetica Prokh. } \\
\text { Rhamnaceae }\end{array}$ & $1-3$ & $2500-3900$ & $A, B, C$ \\
\hline $\begin{array}{l}\text { Rhamnus coriacea (Regel) Kom. } \\
\text { Violaceae }\end{array}$ & 3,5 & $1300-2600$ & $A, B, C$ \\
\hline Viola alaica Vved. & 3,4 & $2000-2800$ & $B, C$ \\
\hline $\begin{array}{l}{ }^{*} \text {. majchurensis Pissjauk. } \\
\text { Elaeagnus }\end{array}$ & 3,4 & $2200-2800$ & B \\
\hline $\begin{array}{l}\text { Elaeagnus songarica Bernh. ex Schlecht. } \\
\text { Umbellifereae }\end{array}$ & 4,8 & $1400-1500$ & $A, B$ \\
\hline Seseli seravschanicum M. Pimen. et Sdobn. & $1-3$ & $2400-3600$ & $A, B$ \\
\hline Conioselinum schugnanicum B. Fedtsch. & $1-4$ & $2000-4100$ & $B, C$ \\
\hline Ferula Linczevskii Korov. & $3-5$ & $1900-2800$ & B \\
\hline F. Karategina Lipsky ex Korov. & $1-4$ & $1800-3500$ & C \\
\hline `Semenovia bucharica (Schischk.) Mandel. & $1-4$ & $2100-3600$ & $B, C$ \\
\hline Lepechiniella sarawschanica (Lipsky) M. Pop. & $1-3$ & $2500-4200$ & $B, C$ \\
\hline L. minuta (Lipsky) M. Pop. & 3 & $2900-3000$ & C \\
\hline Lappula rupicola Zak. & 3 & $2800-3000$ & A \\
\hline${ }^{\star}$ Eritrichium subjacquemontii M. Pop. & 1 & $3800-4000$ & B \\
\hline $\begin{array}{l}\text { Rochelia claviculata M. Pop. et Zak. } \\
\text { Limoniaceae }\end{array}$ & 3,4 & $2200-2900$ & $B, C$ \\
\hline Acantholimon parviflorum Regel & $1-5$ & $1200-3900$ & $B, C$ \\
\hline A. Komarovii Czerniak. ex Lincz & $2-4$ & $2500-3400$ & $B, C$ \\
\hline A. velutinum Czerniak. ex Lincz. & $1-4$ & $2300-4600$ & B \\
\hline A. anzobicum Lintch. & $1-3$ & $2400-3600$ & C \\
\hline `Limonium Komarovii Ik.-Gal. ex Linch. et Czuk. & $3-6$ & $1800-2800$ & $B, C$ \\
\hline $\begin{array}{l}\text { Eremolimon Fajzievii (Zak. ex Lincz.) Lincz. } \\
\text { Labiatae }\end{array}$ & $4-6$ & to 1300 & B \\
\hline Scutellaria picta Juz. & 3 & $2100-2800$ & B \\
\hline *S. haesitabunda Juz. & 2,3 & $2500-3000$ & $B, C$ \\
\hline S. poëcilantha Nevski et Juz. & 3,4 & $1400-2300$ & $B, C$ \\
\hline S. rubromaculata Juz. et Vved. & 3,4 & $2000-2200$ & $A, B$ \\
\hline S. orbicularis Bunge & 4,5 & $1200-2500$ & $A, B, C$ \\
\hline Nepeta tytthantha Pojark. & 3,4 & $1800-2000$ & B \\
\hline
\end{tabular}




\begin{tabular}{|c|c|c|c|}
\hline Families / species & $\begin{array}{c}\text { Type of } \\
\text { ecosystems }\end{array}$ & $\begin{array}{l}\text { Altitude } \\
\text { m a.s.l. }\end{array}$ & Subregion \\
\hline N. maussarifi Lipsky & $3,4,7$ & $2100-3000$ & B \\
\hline Eremostachys sarawschanica Regel & $2-4$ & $2200-3200$ & $B, C$ \\
\hline E. mogianica M. Pop. & $4-6$ & $1000-1500$ & $A, B$ \\
\hline Lagochilus kschtutensis Knorr. & $2-6$ & $1800-2900$ & $A, B, C$ \\
\hline Salvia Komarovii Pobed. & 4,5 & $2000-2100$ & $A, B$ \\
\hline Perovskia virgata Kudr. & 2,3 & $1800-2900$ & C \\
\hline \multicolumn{4}{|l|}{ Rubiaceae } \\
\hline${ }^{\star}$ Asperula pamirica Pobed. & $2-6$ & $1200-3800$ & $B, C$ \\
\hline A. Czukaviniae Pahom. et Karim. & 3,4 & $1800-2600$ & $B, C$ \\
\hline Galium Vassilczenkoi Pobed. & $1-5$ & $2000-3600$ & $B, C$ \\
\hline \multicolumn{4}{|l|}{ Valerianaceae } \\
\hline Valeriana Kamelinii B. Sharipova & 2,3 & $2550-3200$ & B \\
\hline \multicolumn{4}{|l|}{ Campanulaceae } \\
\hline${ }^{\star}$ Campanula Lehmanniana v. integerrima Bunge & $3-6$ & $400-2000$ & $A, B$ \\
\hline C. hissarica R. Kam. & 3,4 & $1800-2500$ & B \\
\hline Asyneuma baldshuanicum (O. Fedtsch.) Fed. & $3-6$ & $750-2600$ & $A, B, C$ \\
\hline A. debile Fed. & $3-6$ & $1100-2100$ & B \\
\hline A. attenuatum (Franch.) Bornm. & $2-4$ & $1400-3400$ & $A, B, C$ \\
\hline Cryptocodon monocephalus (Trautv.) Fed. & 3,4 & $1600-1700$ & B \\
\hline \multicolumn{4}{|l|}{ Compositae } \\
\hline${ }^{\star}$ Anaphalis latifolia Kinz. et Vainberg & 3,4 & $1800-2800$ & C \\
\hline Inula glauca C. Winkl. & $4-6$ & $1500-2500$ & $B, C$ \\
\hline Cousinia Fedtschenkoana Bornm. & $1-3$ & $2500-3500$ & C \\
\hline C. ulotoma Bornm. & 5,6 & $1500-1800$ & B \\
\hline${ }^{\star}$ C. alpestris (Bornm.) Juz. & $2-4$ & $2400-2600$ & C \\
\hline C. ferruginea Kult. & $1-4$ & $1800-3500$ & C \\
\hline C. princeps Franch. & $3,4,6$ & $1600-3000$ & $A, B, C$ \\
\hline C. sarawschanica C. Winkl. & $1,3,4$ & $2000-3500$ & A \\
\hline C. splendida C. Winkl. & $2-4$ & $2300-3300$ & $B, C$ \\
\hline${ }^{\star}$ C. stephanophora C. Winkl. & $1-4$ & $1700-4000$ & C \\
\hline `Jurinea Komarovii lljin & $1,2,4$ & $2300-3900$ & $B, C$ \\
\hline Cirsium Rassulovii B. Sharipova & 3,7 & $2300-2500$ & $B, C$ \\
\hline Onopordum seravschanicum Tamamsch. & 2,3 & $2700-3000$ & C \\
\hline `Scorzonera Albertoregelia C. Winkl. & 3,4 & $2400-3000$ & B \\
\hline Taraxacum Kovalevskiae Vainberg & $1-3$ & $2300-3800$ & B \\
\hline${ }^{\star} T$. pseudobrevirostre Vainberg & 1,2 & $2800-4000$ & $A, B, C$ \\
\hline T. seravschanicum Schischk. & 3,4 & $2500-3000$ & B \\
\hline T. Vassilczenkoi Schischk. & $1-3$ & $3000-3700$ & $A, C$ \\
\hline T. anzobicum Schischk. ex Vainberg & $2-4$ & $1800-3400$ & C \\
\hline
\end{tabular}

Type of ecosystems: 1 - high mountain desert ecosystems, 2 - high mountain meadow and steppe ecosystems, 3 - mid-mountain conifer forest ecosystems, 4 - mid-mountain mesophyllic forest ecosystems, 5 - mid-mountain xerophytic light forest ecosystems, 6 - mid-low-mountain semisavanna (savannoide) ecosystems, 7 - wetland ecosystems, 8 - agroecosystems. Geobotanical regions: A - Western Zeravshan, B - Central Zeravshan, C - Eastern Zeravshan; ${ }^{\star}$ - species not confirmed by authors. 
In the Zeravshan Range and in its geobotanic region there are 190 species of endemic vascular flora (Abdusalâmov 1988, Tab. 1). They form 25 families and 84 genera. The most numerous endemic families include Leguminoseae (56), Compositeae (19), Crucifereae (13), Rosaceae (13), Labiateae (12), Ranunculaceae (11), Gramineae (10), Umbellifereae (10), Liliaceae (6), Limoniaceae (6), while the most numerous endemic genera are: Astragalus, Oxytropis, Cousina, Potentilla, Scutellaria, Taraxacum, Delphinium, Ranunculus, Acontholimon, Nepeta. Among unidentified endemic species those from the families Leguminoseae (17), Compositeae (6), Crucifereae (5), Rosaceae (5), Ranunculaceae (4), Liliaceae (3) and Umbelifereae predominate (2). In terms of life forms, endemic plants of that area are dominated by perennial species (156), plants and shrubs (20), biennial (7), trees (6), annual species (1). All these species show specific features of adaptations to life in extreme mountain conditions (Safarov 2013ab).

The largest number of endemic species occurs between the altitudes of 1,400 and 4,000 m a.s.l. The representation of these species within the Zeravshan Geobotanic Region are shown in Table 1. Naturally, the endemic species also grow above and below the suggested altitude ranges (Rahmonov et al. 2014). The analysis shows that endemic species are most common in the phytocoenoses involving juniper species, so it can be said that juniper forests represent a potential habitat for these taxa. Disruption of ecological processes within juniper forests may negatively affect the number of endemic species.

\section{Ecological and cultural role of juniper forest ecosystems for Central Asian societies}

Juniper species are long-living trees, whose age may reach over 1,000 years (Muhamedŝin \& Talancev 1982; Ismailov 1974; Opała et al. 2017). In their annual growth rings they record changes in climatic conditions, especially fluctuations in precipitation and temperature, and therefore constitute a unique natural archive. Trees are witnesses to natural changes taking place over hundreds of years, or even a millennium (Opała et al. 2017; Owczarek et al. 2017).

The importance of juniper forests relies on the fact that, on the one hand, they protect water resources and inhibit erosion, while on the other they are a source of good quality building material and firewood. Currently juniper forests of Tajikistan, including those in the Zeravshan Range, are significantly distorted as a result of chaotic, uncontrolled and excessive felling, as well as cattle grazing. It should be noted that all forests of Tajikistan are the first category ecosystems: they play an important role in nature protection in general, and especially in soil protection. Therefore, forest felling is categorically prohibited. However, what has been commonly observed in recent times due to lack of fuel, is intense tree felling, clearly visible in the Kulikalon Basin and in other parts of the Zeravshan Valley. This, in turn, negatively affects the processes of forests renewal by enhancing surface runoff on slopes as well as soil degradation, thus preventing the growth of young trees.

Protective and anti-erosion role of woody juniper specimens is conditioned by a strong root system. Most of the juniper specimens create large and extensive root systems extending far from the crown zone, which largely prevents erosion and the formation of rubblemud runs. In the presence of several juniper biogroups their root systems get intertwined. Studies have shown that in dry habitats roots are long and branched. The roots themselves create habitats for other herbaceous species, which also partially inhibits erosion by creating ground cover.

An important anti-erosion role is also played by juniper forest floor, and is conditioned by its thickness and physicochemical properties. The bulk amount of organic fall are scaly leaves, the decomposition of which is very slow. The biological cycle is very weak, and at high altitudes significantly slower or even inhibited. The space under juniper crowns serves as a kind of filtering window, 


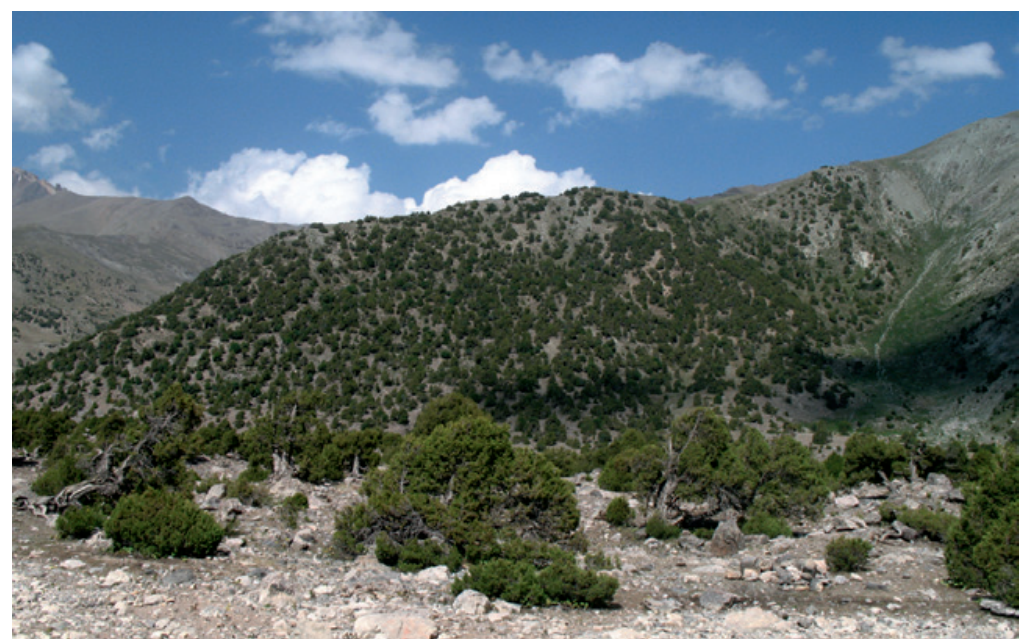

Figure 8. Natural juniper forest in the southern slopes of Zeravshan Mountains (photo: O. Rahmonov)

stopping water from snow and glacier melting, as well as halting torrential rains, thus preventing the erosion of surface soil horizons. Even heavy rains $\left(10-20 \mathrm{~mm} \cdot \mathrm{h}^{-1}\right)$ are easily absorbed by the litter and introduced into intrasoil circulation. Juniper litter is capable of storing moisture for a long period of time. This moisture stored in juniper forests has a significant impact on the surrounding plant and soil ecosystems. Hence, the destruction of juniper forests leads to the deterioration of regimes of mountain rivers and more frequent instances of mud-rubble flows that destroy landscapes and human settlements located downhill. Protecting steep slopes by juniper ecosystems is largely conditioned by the improvement of the physical properties and water conditions in the soil not only in dense stand areas, but also in light forests. Today, the most natural juniper forest fragments (Fig. 8) are located in the eastern and central parts of the Zeravshan Geobotanic Region at an altitude of 3,000 m a.s.l.

Numerous useful juniper features have drawn human attention for a long time. Softness, flexibility, balsamic fragrance, resistance to rotting, and nice wood texture - are features that make it useful in various areas, such as woodturning, music industry, construction and others. In the pharmaceutical and spirit industry, leaves, young branches and cone berries are still widely used (they contain up to $5 \%$ essential oils). In the mountains juniper is the only building material, and in the Middle Ages mining, pottery and forges were based mainly on juniper wood as fuel material. Juniper beams support well-known wooden objects in Bukhara and Samarkand, proving the past presence of powerful forms of woody juniper in the area. Currently such specimens can be found, among others, by Lake Iskanderkul, in Kulikalon and in the Archamajdan Valley. These are remote areas located in high mountains.

Throughout Central Asia, a religious motif of nature protection is observed in the case of individual trees, regardless of species. In the Zeravshan Valley also juniper plays such a role. This is primarily Juniperus seravschanica as it grows at a relatively low altitude. In these areas individual specimens of magnificent trees (fewer and fewer of them) evoke respect in every person. Preservation of such specimen is seen as God's will or is related to the existence of a mazor, i.e. a sacred place. In the culture of the majority of Asians (and not only) mazor is a place of repentance and reflection. People make pilgrimages to such places to leave their sins, prayers and thanks. Such places are also in other part of the World 

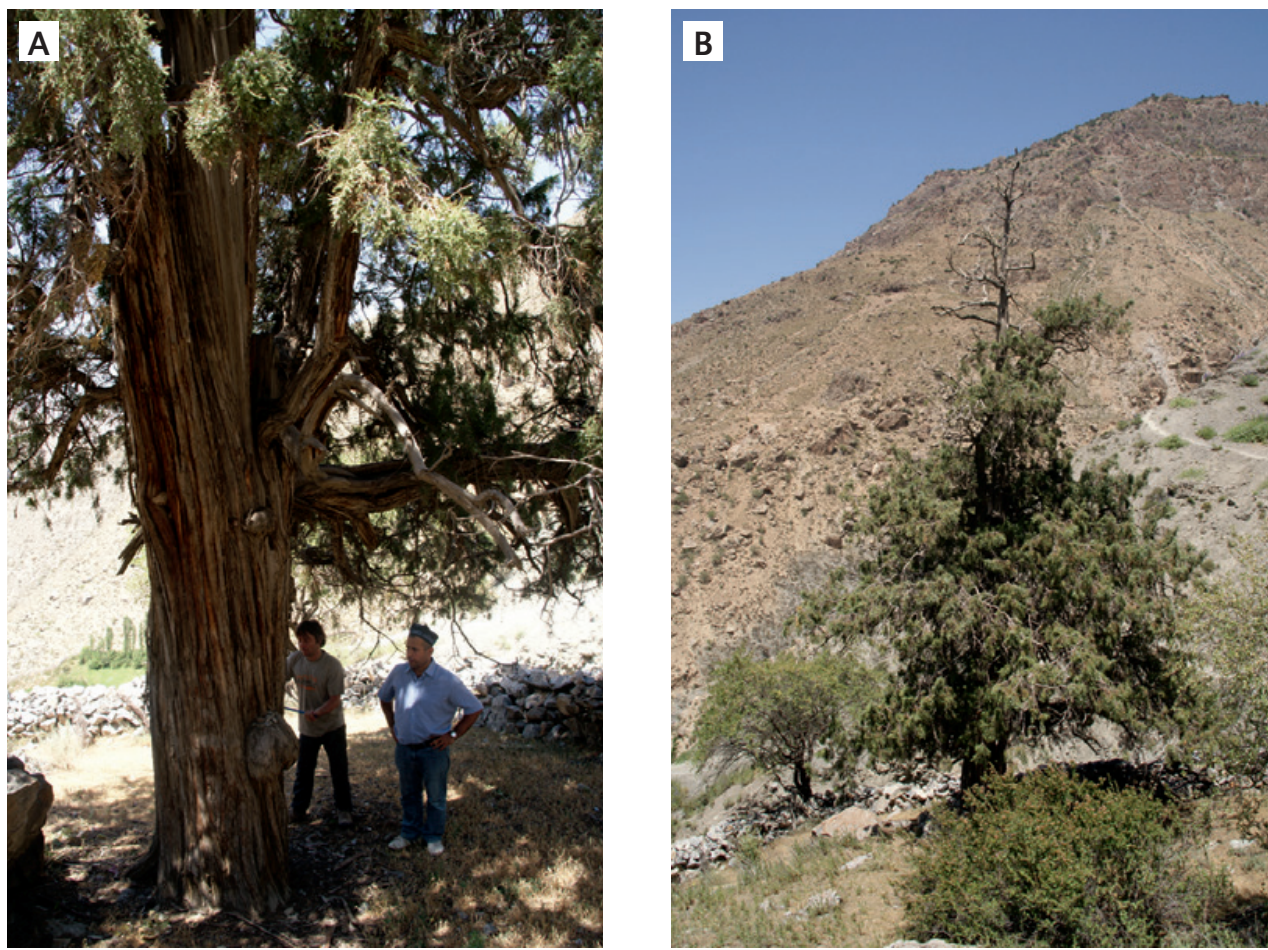

Figure 9. Individual of Juniperus seravschanica, known as Bursi Boboi Mullo Mirzo - object of religious worship: A - lower part of trunk (photo: M. Opała-Owczarek), B - died and dried peak of tree (photo: O. Rahmonov)

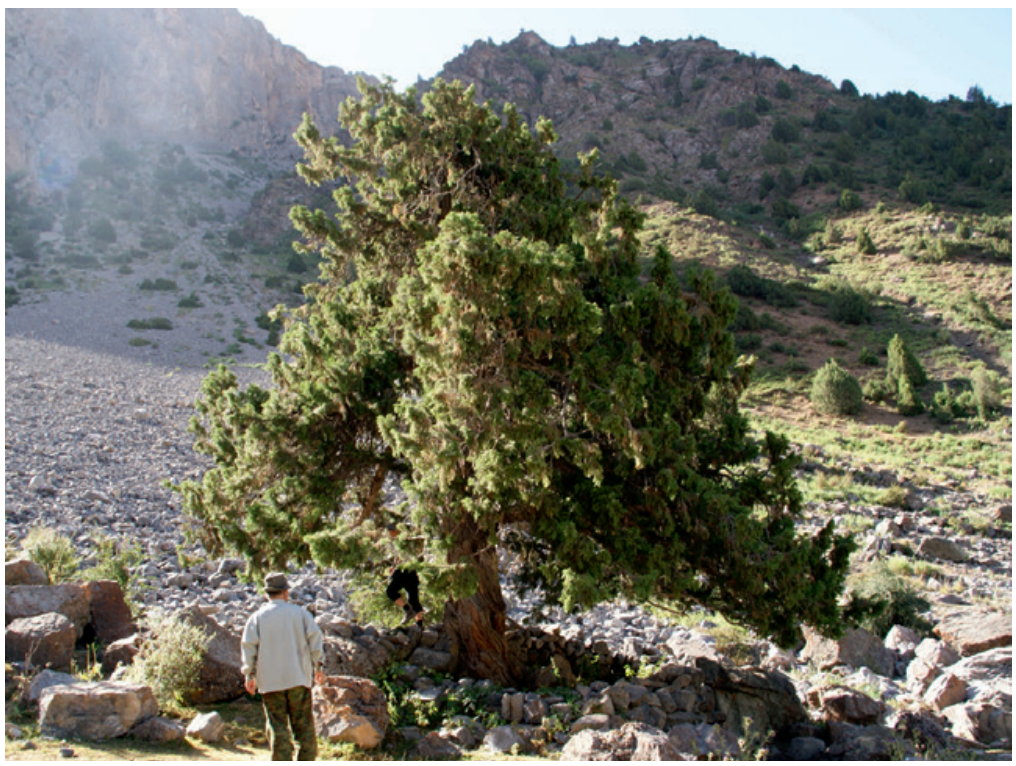

Figure 10. Juniperus seravschanica known as Bursi Taburga - object of religious worship (photo: O. Rahmonov) 
(Benvenisti 2000) and the landscape have different typology (Myga-Piątek 2012)

In Artuch (town in the central part of the Zeravshan Range) three mazors related to Juniperus seravschanica have been preserved. One consists of several specimens of the Zeravshan juniper known as juniper of Bursi Boboi Mullo Mirzo, which includes his family tomb. One of the junipers has a shelf-like bulge, which is also wart-like. Three stones are on this shelf at all times. The local population believes that this juniper cures warts, so a person with a wart can come and touch (grease) the warts with this stone, then discard the stone, and replace it with a new stone (Fig. 9AB).

The second object is called Bursi Taburga (Fig. 10). It is a single tree within a large valley. This juniper tree is called 'the tree of wishes and happiness'. Being under it you need to tear a piece of your own clothes, say a wish and promise, and then tie the piece of cloth on a branch. If the dream gets fulfilled, you also need to fulfill the promise. There are many such trees, also around Lake Iskanderkul.

The third object is located at the foot of the next mazor called Home of Sheich, where water flows from the heart of the mountains. The surroundings of this fracture-karst spring are overgrown with lush high-mountain vegetation, representing a natural ecological system. Before World War II a small terrace was built there of dry old junipers of the local origin (Fig. 11).

Felling trees in these places, according to people's belief, may result in a variety of unfortunate events, including serious illnesses in people who have done so. People may frequent such places only with the matters of God. They are considered pure and spiritually enriching. The age of these sacred trees was determined dendrochronologically to be 500 years (Boboi Mullo Mirzo), 325 years (Bursi Taburga) and 150 years (Chudzi Shajchchona).

\section{Human impact on destabilisation of juniper ecosystems}

Good accessibility, warm and sunny summer, fresh mountain air saturated with resinous smell of junipers made this area extremely popular among mountain lovers in the Soviet

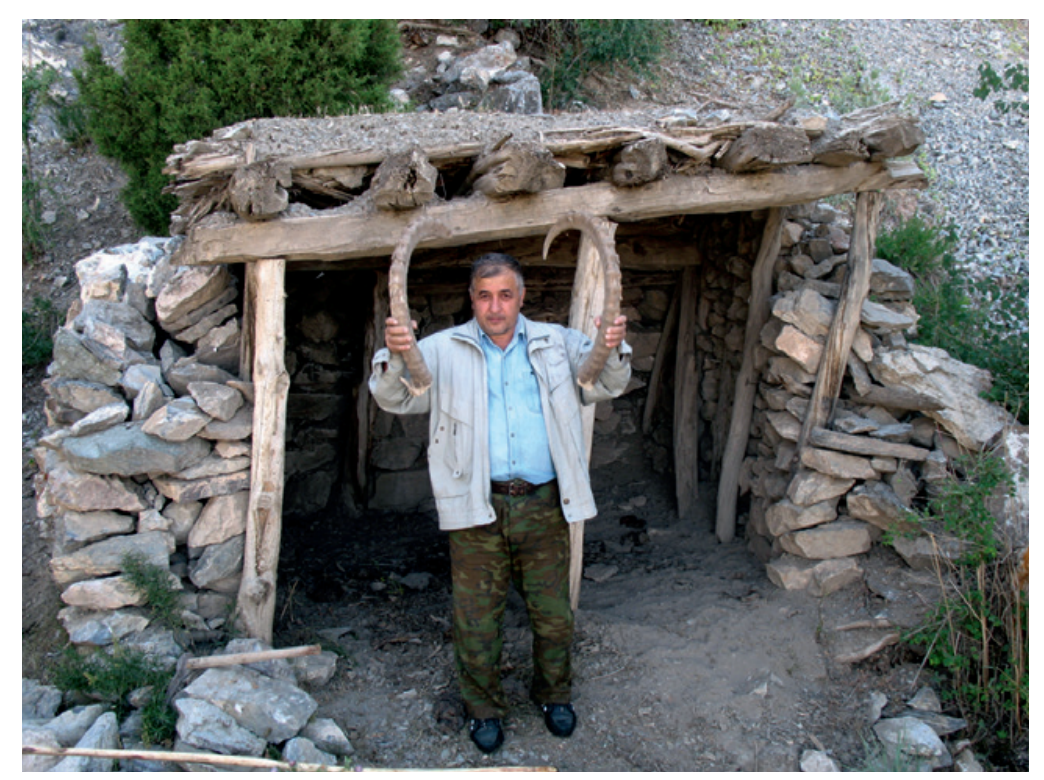

Figure 11. The high-mountain sacred temple built of juniper beams; note the Marco Polo sheep horns near-threatened species in the entire Pamirs region (photo: O. Rahmonov) 
times. In the last ten years, after the political stabilisation, this region has become an object of interest of international mountaineering organisations, supporters of extreme sports and traditional mountain tourists. Unregulated and unsupervised tourism has become an additional and serious anthropopressure factor in the region, which remains traditional in terms of the economic activity of the local population. This landscape is very sensitive. As a result, the functioning of the entire alpine ecosystem may get disturbed. Besides tourism, juniper forests (open low density forests) of the area are currently exposed to largescale uncontrolled felling. Several dozen years ago juniper trees (predominantly Juniperus seravschanica and J. semiglobosa) were mainly cut down by the inhabitants of small mountainous settlements, so-called kishlaks, in little quantities and exclusively for their own use. The inhabitants of kishlaks made their living on shepherding. In the Soviet times a significant amount of food was brought into the settlements. So there existed some kind of ecosystem equilibrium and the human activity did not constitute a significant threat to nature.

Despite poor accessibility, mountain ecosystems in Central Asia have been the subject of strong anthropopressure over the millennia. The Silk Route, joining China and India with the Mediterranean Sea Region, has been well known for over 2,000 years. The most characteristic human activity in the Alay mountain system (also in the Fann Mts.) has been mass-deforestation of juniper forests for combustible, timber and industrial needs. Deforestation has contributed to the development of soil erosion and significant irreversible environmental changes over large areas. Today only small fragments of the investigated area are covered by natural forests (with Juniperus seravschanica Kom. and J. turkestanica Kom.), and most of the territory is under the negative influence of ecological and landscape changes. Juniper forests theoretically belongs to sensitive ecosystems because of extreme environmental conditions with strict parameters of ecological niches and biological productivity. So, a relatively weak external influence can lead to the degradation of Juniperus communities, and thus the natural environment. On the other hand, these ecosystems have functioned for centuries and have survived to modern times under the influence of both climate change and human impacts. Contemporary forest degradation is associated with increased human impact over recent decades.

The year 2002 was proclaimed by the UN as the International Year of Mountains, the motto of which "We are all mountain people" testifies to the importance of the problem. The United Nations University monitors current scientific research concerning mountain ecosystems in different regions of the world. Central Asia is represented in this program only by the Eastern Pamir, where some investigation was carried out over 10 years ago (Jansky et al. 2002).

\section{Summary}

The mountain environment of the Zeravshan Range (e.g. the Fann Mts.), as every alpine environment, is exceptionally sensitive to the influence of external factors, both natural and anthropogenic. Besides other factors characteristic for alpine ecosystems, the biota and soils of the Zeravshan Range experience arid conditions (mountainous semi-desert). Ecosystems of juniper forests develop very slowly, and trees take hundreds of years to grow, reaching sometimes the age of a thousand years. These forests, due to their biomass, plant litter, shadow and other ecological conditions, are a crucial link in the system of bio-geocenotic connections in the study area. Cutting down the forests is therefore a trigger mechanism to destruction of the entire ecosystem.

The Zeravshan region and its unique ecosystems may be considered as a natural laboratory for different types of scientific research, because of varied environmental conditions and natural processes, which can be observed there. The occurrence of centuries-old living trees (Juniperus seravschanica, J. semiglobosa) and dead wood provides opportunities for reconstruction of climatic conditions and 
natural processes of the past using dendrochronological analyses.

From a scientific standpoint, such objects are of great importance in the reconstruction of the natural environment. The presence of these old trees testifies to the fact that in the past the surrounding areas were covered with such tree stands and ecological systems. It also testifies humans are able to destroy high mountain ecosystems in a short time. These habitats are sensitive in nature, and their regeneration takes a long time. In a cultural sense, these objects influence human character. High level of endemism in this area is related to natural conditions: geological structure, the presence of huge mountain ranges, as well as climate, particularly microclimate. They favour the formation

\section{References}

AbdusalÂmov I.A. (ed.), 1988. Krasnaâ kniga Tadžiskoj SSR. Dušanbe: Izdatel stvo Doniš, pp. 163-328.

Abrorov H., 2005. Potenciali iktisodi va zahirahoi obii vodii Zarafšon. Dušanbe.

Abrorov H., Šermatov N., 2010. Features of the hydrological mode of the river Zerafshan and its big inflows. Vestnik Tadžiskogo Nacional nogo Universiteta, Seriâ Estestvennyh Nauk, vol. 3, no. 59, pp. 294-301.

Benvenisti M., 2000. Sacred landscape. The buried history of the Holy Land since 1948. Berkeley, Los Angeles, London: University of California Press.

Borŝov I.G., 1865. Materialy dlâ botaničeskoj geografii Aralo-Kaspijskogo kraâ. Priloženie k 7-mu tomu. Zapiski Imperatorskoj Akademii Nauk, no. 1.

ČUKaVInA A.P., 1984. Flora Tadzhikskoi SSR, vol. VII, Leningrad: Izdatel'stvo Nauka.

GonČAROV N.F., 1937. Rajony flory Tadžikistana i ih rastitel' nost' [in:] Flora Tadžickoj SSR, vol. V, Moskva-Leningrad: Izdatel'stvo Nauka, pp. 7-94.

GrIGOR`ev Û.S., 1944. Očerk rastitel ’nosti bassejna Srednego Zarafšana. Izdatel'stvo AN SSSR, no. 4 , pp. 25-45. of the mosaic, isolated various biotopes, and the hindrance of migration of species over orographic barriers.

\section{Acknowledgments}

The authors wish to thank local people from Artuch District (especially Boboi Mulo Mirzo for accessing of sacred trees for the study) and Rahmonov family for their hospitality and assistance for everything. Part of research was supported by the Polish National Science Centre (Grant No. 380 013/09/B/ST10/00634).

Editors' note:

Unless otherwise stated, the sources of tables and figures are the authors', on the basis of their own research.

Hagedorn F., Mulder J., Jandl R., 2010. Mountain soils under a changing climate and land-use. Biogeochemistry, vol. 97, no. 1, pp. 1-5.

Ismailov M.I., 1974. A botanical-geographical overview of Junipers (Junipers L.) from the perspective of their origin and evolution [in:] M.I. Ismailov (ed.), Questions of ecology and geography of plants, Dushanbe: Izdatel'stvo Donish, pp. 15-40.

Ismallov M.I., 1985. Flora bassejna Iskander-dar `i. Akademiâ Nauk Tadžikskoj SSR, Biologičeskaâ otdeleniâ.

Ismailov M.I., Darvoziev M., Sadikov H.H., 2010a. The ecosystems of juniper of Upper Zeravshan under threat. Vestnik Tadžiskogo Nacional ’ nogo Universiteta, Seriâ Estestvennyh Nauk, vol. 3, no. 59, pp. 259-262.

Ismailov M.I., DarvozIeV M., SadikOv H.H., $2010 b$. Phytocoenological classification of Junipers forest. Vestnik Tadžiskogo Nacional' nogo Universiteta, Seriâ Estestvennyh Nauk, vol. 3, no. 59, pp. 247-250.

Ismailov M.I., SadiKov H.H, DarVoziev M., 2012. The main features of the vegetation basin Iskander. Vestnik Tadžiskogo Nacional' nogo Universiteta, Seriâ Estestvennyh Nauk, vol. 1, no. 1, pp. 167-174.

JANSkY L., IVES J.D., FuruyashikI K., Watanabe T., 2002. Global mountain research for sustainable 
development. Global Environmental Change, vol. 12, no. 3, pp. 231-239.

Kamelin R.B., 1979. Kuhistanskij okrug gornoj Srednej Azii. Leningrad: Izdatel'stvo Nauka.

KINZIKAEVA G.I., 1988. Flora Tadžickoj SSR, vol. IX, Leningrad: Izdatel'stvo Nauka.

KoČKAREVA T.F., 1986. Flora Tadžickoj SSR, vol. VIII, Leningrad: Izdatel'stvo Nauka.

Konnov A.A., 1973. Flora archovnikov Šakhristana. Dušanbe: Izdatel'stvo Doniš.

KudRATOV I., 1985. Lišajniki gornogo Zeravšana. Dušanbe: Izdatel'stvo Doniš.

KUTEMINSKIJ V.Â., 1960. Obŝie zakonomernosti vertikalnoj zonal 'nosti i klasifikacii počv Tadžikistana. Doklady počvovedov, agrohimikov i melioratorov k VII meždunarodnomu kongressu počvovedov. Akademiâ Nauk Tadžiskoj SSR.

KuteminskiJ V.ÂA., LeOntY`eVA R.S., 1966. Počvy Tadžikistana. Dušanbe: Izdatel'stvo Irfon.

LIPSKIJ V.P., 1902. Flora Srednej Azii, t.e. Russkogo Turkestana i hanstva Buhary i Hevy. Trudy Tiflisskogo botsada, vol. 7, čast` 1, no. 1.

MiCKLIN P., 2007. The Aral Sea Disaster. Annual Review of Earth and Planetary Sciences, vol. 35, pp. 47-72.

Mittermeier R.A., Gil P.R., Hoffmann M., Pilgrim J., Brooks T., Mittermeier C.G., LamorEUX J., DA FonseCA G.A.B., 2005. Hotspots revisited: Earth 's biologically richest and most endangered terrestrial ecoregions. Mexico City: Agrupacion Sierra Madre.

MuhamedŝIn K.D., TalanceV N.K., 1982. Možževelovye lesa (lesa, redkolesya, zarosli). Moskva: Lesnaâ promyšlennost`.

MygA-PIĄTEK U., 2012. Krajobrazy sakralne i religijne - próba umiejscowienia w typologii krajobrazów kulturowych. Prace Komisji Krajobrazu Kulturowego, vol. 17, pp. 13-23.

OvČINNIKOV P.N., 1940. K istorii rastitel' nosti juga Srednej Azii. Sovriemennaya botanika, no. 3, pp. 23-48.

OvČınNikov P.N., 1957. Osnovnye čerty rastitel 'nosti i rajony flory Tadžikistana [in:] P.N. Ovčinnikov (ed.), Flora Tadžickoj SSR, vol. I, Leningrad: Izdatel'stvo Nauka, pp. 1-15.

OvČINNIKOV P.N. (ed.), 1957, 1963, 1968, 1975, 1978, 1981. Flora Tadžickoj SSR, vol. I-VI, Leningrad-Moskva: Izdatel'stvo Nauka.
Opata M., Niedźwiedź T., Rahmonov O., 2013. Dendrochronological potential of Ephedra equisetina from Zaravshan Mountains (Tajikistan) in climate change studies. Contemporary Trends in Geoscience, vol. 2, no. 1, pp. 48-53.

Opata M., Niedźwiedź T., Rahmonov O., OwczaREK P., MAŁARZEWSKI Ł., 2017. Towards improving the Central Asian dendrochronological network - new data from Tajikistan, Pamir-Alay. Dendrochronologia, vol. 41, pp. 10-23.

Owczarek P., Opala-Owczarek M., Rahmonov O., MendeCKI M., 2017. 100 Years of earthquakes in the Pamir region as recorded in juniper wood: A case study of Tajikistan, Journal of Asian Earth Sciences, vol. 138, pp. 173-185.

Rahmonov O., Holbegov M., Szczypek T., SnytKo V.A., Klys G., Rahmonov M., 2014. The consequences of vegetation degradation under the influence of anthropogenic activity in the territory of the Zarafshan Range (Western Tajikistan). Geography and Natural Resources, vol. 35, no. 2, pp. 193-197.

Rahmonov O., Majgier L., Andrejczuk W., Banaszek J., Karkosz D., Parusel T., Szymczyk A., 2013. Landscape diversity and biodiversity of Fann Mountains (Tajikistan). Ekologia (Bratislava), vol. 32, no. 4, pp. 388-395.

Rahmonov O., Niedźwiedź T., Opata M., MatarzeWski Ł., OWCZAReK P., 2016. Landscape degradation and its effect on the soil-vegetation relations within juniper forest in the Fann Mountains (Western Pamir-Alay) [in:] L. Halada, A. Bača, M. Boltižiar (eds.), Proceedings of the 17th International Symposium on Landscape Ecology, Nitra, pp. 168-175.

Rahmonov O., Rahmonova M., Snytko V.A., SzCZYPEK T., 2011a. Anthropogenic disturbance to vegetation on the polygon-transect in the $\mathrm{Ku}$ likalon depression (Tajikistan). Geography and Natural Resources, vol. 32, no. 4, pp. 386-393.

Rahmonov O., Snytko W.A., Szczypek T., KŁys G., 2011b. Wpływ antropopresji na roślinność pótnocnej części Gór Fańskich (na przykładzie Kotliny Kulikalońskiej). Acta Geographica Silesiana, vol. 10, pp. 64-73.

Rahmonov O., Szczypek T., NiedźWiedź T., MygaPiątek U., Rahmonov M., Snytko V.A., 2017. The human impact on the transformation of juniper forest landscape in the western part of the PamirAlay range (Tajikistan). Environmental Earth Sciences, vol. 76, no. 8, pp. 324-340. 
Rasulova M.R. (ed.), 1991. Flora Tadžikskoj SSR. Vol. X, Leningrad: Izdatel'stvo Nauka.

Saidov M.K., Džuraev A., 2011. Osnovnye ékolobiologičeskie osobennosti rastite 'nosti $\mathrm{ka}$ menistyh osypej zakaznika Iskaderkul' [in:] M.K. Saidov (ed.), Ékologičeskie osobennosti biologičeskogo raznoobraziâ dikoratuŝih piŝevyh rastenij Tadžikistana, Kostanaj, pp. 39-52.

SADIKOV H., 2012. Arčovniki bassejna reki Iskander (Tadžikistan). Saarbrücken: Lambert Academic Publishing.

Sadikov H., Darvoziev M., 2011. About woodshrubs communities of the floodplain of the river of Iskender (Tajikistan). Vestnik Tadžiskogo Nacional 'nogo Universiteta, Seriâ Estestvennyh Nauk, vol. 6, no. 70, pp. 70-72.

Safarov N.M., 2013a. Analiz žiznennyh form flory Centralnogo Pamiro-Alâa. Doklady Akademiâ Nauk Respubliki Tadžikistana, vol. 56, no. 8, pp. 643-648.

Safarov N.M., 2013b. Geografičeskij analiz flory Centralnego Pamiro-Alaâ. Doklady Akademiâ Nauk Respubliki Tadžikistana, vol. 56, no. 7, pp. 569-573.

Safarov N.O., 1974. O fitocenotičeskih osobennostâh bereznâkov $v$ bassejne ozera Iskanderkul'. Tezisy dokladov resp. konf. molod. učen. i spec. TadžSSR, Dušanbe: Doniš, pp. 37-39.

Sidorenko G.T., StrižeVA T.G., ČukAVIna A.G., 1964. Rastitel 'nost' bassejna reki Zeravšan. Materialy po proizvoditel `nym silam Tadžikistana, vol. 2, pp. 113-129.

STANÛKOVIČ K.V., 1963. Polynnye pustyni Tadžikistana, ih dinamika i vozrastnoj sostav édifikatorov. Duŝanbe: Akademiâ nauk Tadžikskoj SSR.

STANÛKOVIČ K.V., 1973. Rastitel 'nost' gor SSSR. Duŝanbe: Donish.

TroHimov A.K., 1968. Prirodnye usloviâ i resursy [in:] Atlas Tadžiskoj SSR. Duŝanbe-Moskva: GUGiK.

VInNiČENKo G.P., TADŽıBEKOV M., 2010. Évolûciâ rel'efa Pamira i Gissaro-Alaâ $v$ fanerozoe. Doklady Akademii Nauk Respubliki Tadžikistan (Geomorfologiâ), vol. 53, no. 11, pp. 879-883.

Williams M.W., Konovalov V.G., 2008. Central Asia Temperature and Precipitation Data, 18792003. Boulder, Colorado: USA National Snow and Ice Data Center, http://nsidc.org/data/ docs/noaa/g02174_central_asia_data/index. html.

ZAKIROV R.Z., 1955. Flora i rastitel 'nost' bassejna reki Zeravŝan. Čast 1, Taŝkent: Izdatel'stvo Akademiâ Nauk Uzbek SSR.

ZAKIROV R.Z., 1961. Flora bassejna reki Zeravŝan. Čast 2, Taŝkent: Izdatel'stvo Akademiâ Nauk Uzbek SSR.

ZaprâgaeV F.L., 1976. Lesnye resursy Pamiro-Alaâ. Leningrad: Izdatel'stvo Nauka.
(C) Oimahmad Rahmonov - Małgorzata Rahmonov Magdalena Opała-Owczarek - Piotr Owczarek Tadeusz Niedźwiedź • Urszula Myga-Piątek (C) Geographia Polonica

(C) Institute of Geography and Spatial Organization Polish Academy of Sciences - Warsaw • 2017
Article first received • April 2017 Article accepted • September 2017 